The classic picture is one of subacute, rapidly progressive dementia, often accompanied by florid psychiatric symptoms including visual and auditory hallucinations, and invariably associated with myoclonus. Indeed, the combination of myoclonus with a rapidly evolving dementia strongly suggests the diagnosis of Creutzfeldt-Jakob disease. A startle reaction may often be elicited. The patient becomes apathetic and confused with a poor memory and is dysphasic. Next he develops dysarthria, bulbar or pseudobulbar palsy appears, and dysphagia is common. Some patients present with cortical blindness, while others develop it in the course of the disease. Ataxia may appear early as evidence of cerebellar damage. Most patients finally become mute, and progressive rigidity and spasticity make them bedbound. Repetitive jerking of the muscles is still evident late in the disease. The duration of survival depends largely on the quality of the nursing care.

Less frequently the disease may pursue a more chronic course without myoclonus but accompanied by muscle atrophy and fasciculations, thus resembling motor neurone disease. This form may be confused with amyotrophic lateral sclerosis, Parkinson's disease, or Alzheimer's disease.

Laboratory investigations are of little help in diagnosis. The blood and cerebrospinal fluid show no abnormalities, apart from occasional evidence of mild liver dysfunction. At first the electroencephalogram shows only non-specific changes but later there may be high-voltage, bilaterally synchronous, polyphasic discharges which become periodic at a rate of one or two a second. A computed tomography scan is of little help because the ventricular enlargement is seldom severe. The diagnosis should be readily apparent clinically, but it may be confirmed by cerebral biopsy. Although the macroscopic appearance of the brain is unremarkable, microscopical examination shows neuronal loss, intense gliosis, and a finemeshed vacuolation suggesting minute accumulations of fluid. This vacuolation-spongiform encephalopathy-has been shown by electron microscopy to be due to vacuoles within the cytoplasm of astrocytes and neurones. The degree of change depends on the stage of the disease.

Research into Creutzfeldt-Jakob disease took off with the first report of its transmission to a chimpanzee by a cerebral biopsy specimen from a patient with the disease. The agent has also been passaged into other laboratory animals, including guinea-pigs, hamsters, and mice. Accidental transmission of Creutzfeldt-Jakob disease from man to man has been reported. ${ }^{1}$ Two young epileptics developed the disease after they had been studied with depth electrodes used previously in a patient with Creutzfeldt-Jakob disease; in another case, a neurosurgeon was affected.

Some time ago precautions were advised in necropsy and operating rooms if Creutzfeldt-Jakob disease was suspected, but the advice was confusing and difficult to put into practice. ${ }^{23}$ The matter has now been fully discussed by Matthews ${ }^{4}$ and by the advisory group on the management of patients with Creutzfeldt-Jakob disease, which has recently made its recommendations to the Chief Government Medical Officers. ${ }^{5}$ This authoritative advice is mandatory for neurologists, neurosurgeons, neuropathologists, and pathologists, all of whom may handle brain tissue from these patients. Psychiatrists may have patients with Creutzfeldt-Jakob disease in their wards and they should also be aware of this report.

Anxieties about the possibility of infection by patients with Creutzfeldt-Jakob disease are entirely rational, but there is no evidence to suggest that they are infectious under general nursing care when proper precautions are taken. These include the use of gloves and disposable gowns in routine nursing procedures such as handling bloodstained dressings or cleaning bed sores. Laboratory specimens should be handled with the special precautions laid out in the code of practice for the prevention of infection in clinical laboratories and postmortem rooms. The recommendations for dealing with patients with Creutzfeldt-Jakob disease suggested by the advisory group are timely and their conclusions will serve to allay present anxieties.

P O BEHAN

Consultant Neurologist and Reader in Neurology,

Institute of Neurological Sciences,

Southern General Hospital,

Glasgow G51 4TF

1 Will RG, Matthews WB. Evidence for case-to-case transmission of Creutzfeldt-Jakob disease. F Neurol Neurosurg Psychiatry 1982;45:235-8.

2 Gajdusek DC, Gibbs CJ Jr, Asher DM, et al. Precautions in medical care of, and handling materials from, patients with transmissible virus dementia (Creutzfeldt-Jakob disease). N Engl f Med 1977;297:1253-8.

3 Brown P, Cathala F, Gajdusek DC. La maladie de Creutzfeldt et Jakob. Précautions pour les gestes diagnostiques, et thérapeutiques: les nécropsies. Rev Neurol (Paris) 1978;134:277-86.

${ }^{4}$ Matthews WB. Spongiform virus encephalopathy. In: Matthews WB, Glaser GH, eds. Recent advances in clinical neurology. 3. Edinburgh: Churchill Livingstone, $1982: 229-38$.

${ }^{5}$ Advisory Group on the Management of Patients with Spongiform Encephalopathy (Creutzfeldt-Jakob Disease (CJD)). Report of the Chief Medical Officers of the Department of Health and Social Security, the Scottish Home and Health Department and the Welsh Office. London: HMSO, 1981:1-5.

\section{Social work: effective or affective?}

In 1980 the Secretary of State for Social Services invited the National Institute for Social Work to make an inquiry into the "role and tasks" of social workers. The report of the working party, chaired by $\mathrm{Mr} \mathrm{P} M$ Barclay, has recently been published. ${ }^{1}$ Its main recommendation is a move to community social work. This speculative idea has already been criticised by Professor Pinker in a lucid minority report. "The concept of community," he argues, "can never be sufficiently well defined to serve as a framework for formal and equitable social policies ..." Evidently there was also a lack of consensus on many other issues. Not surprisingly, then, the document has been received without acclamation in social work circles. ${ }^{2} 3$

Few of the recommendations have a direct bearing on medical practice. Inevitably the multidisciplinary team is mentioned, with the authors alleging that (outside of the psychiatric sphere) the working relation between social workers and doctors is rarely one of equal partners. One barrier is the doubts in some doctors' minds about the ethical accountability of social workers. These doubts may be reinforced by the report's rejection of proposals for a general council of social work, analogous to the General Medical Council.

At the heart of the report-and its reception by doctorsare the familiar questions: what do social workers do? And, what sort of social work is of benefit to medical patients?

Statutory duties apart, social workers undertake two overlapping activities, neither of which is exclusive to them. Social care planning is based on efforts to improve present, or prevent future, social problems; it comprises assessment, practical advice and service, and administrative affairs. 
Counselling or case work is, according to the report, "the process of direct communication and interaction between clients and social workers through which clients are helped to change, or to tolerate, some aspects of themselves or of their environment." The former set of tasks is clearly useful and of practical importance in a modern welfare state; but is the same true of the latter?

Social workers regard counselling as the hallmark of their vocation; yet, as defined above, it is little more than a token occupation, with a resemblance to psychotherapy. ${ }^{4}$ The psychotherapies are not very effective, ${ }^{6}$ generally speaking, and can be harmful. Similarly, three reviews of North American publications on case work effectiveness ${ }^{7-9}$ have shown that counselling has been found ineffective in a variety of settings. Indeed, clients seemed to deteriorate under the effects of social work in half of the studies reviewed by Fischer. ${ }^{7}$

Despite an awareness of these assessments, social workers in Britain have rarely been active in evaluative research. ${ }^{10}$ The first British field experiment compared trained versus untrained case workers in the social care of elderly applicants to a local authority welfare department. ${ }^{11}$ The trained workers' clients made a better social adjustment than the rest. However, these modest social gains were achieved at the expense of much more case work. An evaluation of case work for selfpoisoning patients ${ }^{12}$ found that the rate of repeat self-poisoning stayed the same whether or not patients had case work. Nor has the Samaritans' voluntary counselling altered the suicide rate. ${ }^{13}$ Equally important, though, are the implications of a controlled trial of two court procedures for truancy. ${ }^{14}$ Truants who were allocated to repeated adjournments, rather than to social work supervision, not only returned to school more often but also committed fewer criminal offences. Support for counselling/case work, so far, is disappointingly weak.

A more coherent series of investigations has examined the place of social work in general practice. The first of these suggested that supportive care given by a social worker attached to the practice gave valuable clinical and social benefits to a group of patients with chronic neurotic disorders. ${ }^{15}$ A later report looked into the nature of this social work. ${ }^{16}$ The social worker was concerned with two-thirds of the experimental group of patients. More than two-thirds of her time was given up to practical tasks; counselling alone took up a quarter of her time, and was used with fewer than half of the patients with whom she had continuous contact. Social work activities were, however, found to be unrelated to the patients' outcomes. The study failed to pinpoint the social worker's contribution; but the authors conjectured that an explanation for the overall findings was that the social worker's actions "supplemented the resources which she mobilised, and facilitated a more positive approach by the general practitioner towards the social orbit of morbidity."

Another study assessed the effect of such social work on a group of depressed women attending their general practitioner for treatment. ${ }^{1718}$ Patients in the experimental group were referred to one of four experienced social workers attached to the practices. Women with acute exacerbations of chronic disorders improved on clinical and social measures after social work help; women with more acute conditions did not benefit. Those who responded best had poor relations with their spouse or boyfriend and had practical problems for which they were motivated to seek help.
These positive findings may encourage general practitioners to make use of social workers' more practical skills in the management of chronic neurotic disorders. The results are persuasive; even so, the work has not been replicated and firm conclusions may be premature. At the very least, however, the investigations show the feasibility of controlled trials of social work in medicine.

Altogether, there seems little evidence that counselling/case $\mathbb{D}$ work is an effective pursuit. Social workers could limit their use of this type of activity with patients without much loss. There is, in any case, a discrepancy between social workers' enthusiasm for counselling and the reality of their job. For the meagre research on social workers' activities shows that only a fifth, or less, of their time is spent in counselling. ${ }^{1920}$ There is, however, great potential for social work interventions $\stackrel{\Phi}{\varnothing}$ of a practical and structured kind in medicine, provided these are applied critically. Meanwhile social workers might be well $\overrightarrow{0}$ advised to divest themselves of "the uniform borrowed from the practitioners of psychological medicine,"21 which some describe as the emperor's new clothes.

\section{GREG WILKINSON}

Senior Registrar,

Maudsley Hospital,

London SE5 8AZ

${ }^{1}$ National Institute for Social Work. Social workers: their role and tasks. London: Bedford Square Press, 1982.

${ }^{2}$ Bamford T. The debate begins. Social Work Today 1982;13:1.

3 Jordan B. Social work: back to the Poor Law? New Society 1982;60: 208-10.

4 Prins HA, Whyte MBH. Social work and medical practice. Oxford: Pergamon Press, 1972.

${ }^{5}$ Brewer C, Lait J. Can social work survive? London: Temple Smith, 1980. సం

${ }^{6}$ Smith ML, Glass GV. Meta-analysis of psychotherapy outcome studies. Am Psychol 1977;32:752-60.

${ }^{7}$ Fischer J. Is casework effective ? A review. Social Work 1973;18:5-20.

${ }^{8}$ Wood KM. Casework effectiveness: a new look at the research evidence. Social Work 1978;23:437-58.

${ }^{9}$ Reid WJ, Hanrahan P. The effectiveness of social work: recent evidence. In: Goldberg EM, Connelly N, eds. Evaluative research in social care. Heinemann Educational Books, 1981 :9-20.

${ }^{10}$ Sheldon B. Not proven: social work effectiveness. Community Care 1979; June 14:27-8.

11 Goldberg EM, Mortimer A, Williams BT. Helping the aged: a field experiment in social work. London: George Allen and Unwin, 1970.

12 Gibbons JS, Butler J, Urwin P, Gibbons JL. Evaluation of a social work service for self-poisoning patients. Br F Psychiatry 1978;133:111-8.

${ }^{13}$ Barraclough BM, Jennings C, Moss JR. Suicide prevention by the Samaritans: a controlled study of effectiveness. Lancet 1977;ii:237-8.

${ }^{14}$ Berg I, Consterdine M, Hullin R, McGuire R, Ryrer S. The effect of $\delta$ two randomly allocated court procedures on truancy. British fournal of 3 Criminology 1978;18:232-44.

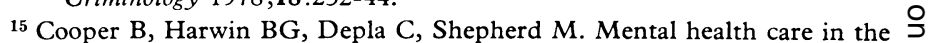
community: an evaluative study. Psychol Med 1975;5:372-80.

${ }_{16}$ Shepherd M, Harwin BG, Depla C, Cairns V. Social work and the o primary care of mental disorder. Psychol Med 1979;9:661-9.

17 Corney RH. Social work effectiveness in the management of depressed women: a clinical trial. Psychol Med 1981;11:417-23.

18 Corney RH, Clare AW. The effectiveness of attached social workers in $N$ the management of depressed women in general practice. British $\sigma$ Fournal of Social Work (in press).

${ }^{19}$ Goldberg EM, Warburton RW, McGuiness B, Rowlands JG. Towards accountability in social work: one year's intake to an area office. British Fournal of Social Work 1977;7:257-83.

${ }^{20}$ Raynes NV, Winny J, Mulgrew K. What do social workers do: a method 0 for classifying social workers' activities. British fournal of Social Work (in press).

${ }^{21}$ Wootton B, Seal VG, Chambers R. Social science and social pathology. London: George Allen and Unwin, 1959.

\section{(1)

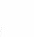 (1)} . 